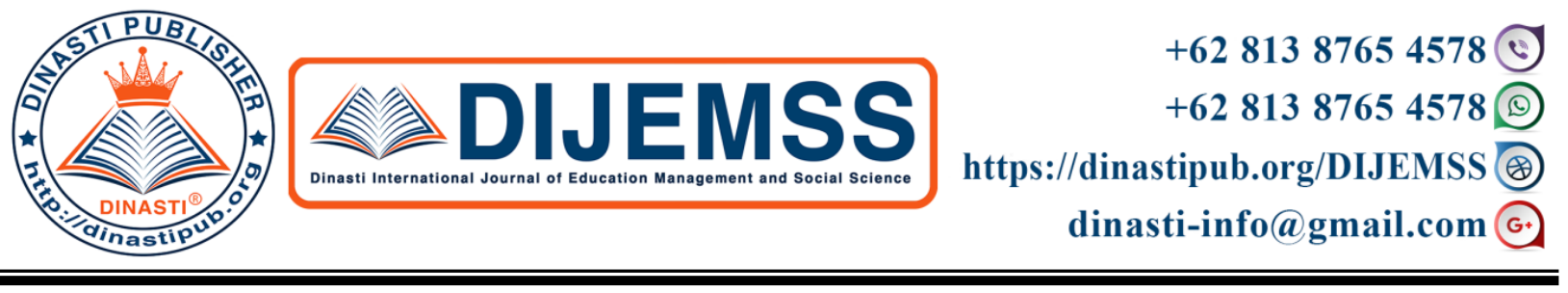

\title{
ANALYSIS OF FACTORS INFLUENCING CONSUMER DECISIONS WHEN CHOOSING LIEN SERVICES AT PEGADAIAN PUBLIC CORPORATION IN EAST LOMBOK
}

\section{Handry Sudiarta Athar}

Postgraduate degree, Mataram University, Lombok, Indonesia

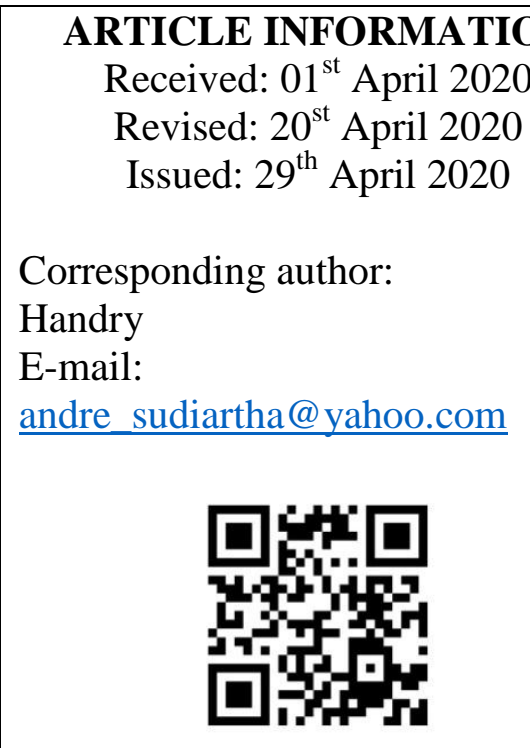

DOI:10.31933/DIJEMSS
Abstract: The aim of this study was to determine whether the interest rate variables, loan procedures, services, credit guarantees and facilities influence the customer's decision to pledge his goods at the Pegadaian Public Corporation in East Lombok. This research is a descriptive research with research location on the 23rd education road in Aikmel, East Lombok. The data collection method is a sample with a sample of 100 respondents, determined on the basis of unintended samples with the Slovenian formula. Techniques for data collection are observation and interview. Data collection tool is a questionnaire. The type of data used is quantitative data and qualitative data with data sources in the form of primary and secondary data. Based on the factor analysis, it has been found that out of the five factors investigated, four factors influence the customer's decision to pledge the goods, grouped into 3 core factors: the first factor has an own value of 1,703 , a combination of variations in credit facilities and guarantees. The second factor has an eigenvalue of 1,022 , in particular from the loan procedure variable. The third factor has an eigenvalue of 1.003 , which is an interest rate variable. And the factor that has the greatest influence is the first factor because it has the highest self-esteem.

Keywords: Consumer Decisions; Pledge Service; Pawnshop 


\section{INTRODUCTION}

The main purpose of establishing a company is to offer added value to the company, employees, owners as well as to customers or customers of the company (Dinawan, 2010). Another goal is to maintain the operational activities of the company by bringing profit to the company. One is through the marketing of products and services produced by the relevant company. Services are basically all economic activities the results of which are not physical or constructive products, which are usually consumed at the same time as the time they are produced and offer added value (such as safety, entertainment, pleasure or health) or solving the problems consumers encountered (Lupiyoadi, 2001: 5). Services are basically all economic activities with output in addition to products in physical form, which are consumed and produced at the same time, and which offer added value and elusive principles for their first buyers (Zeithaml and Bitner, 2000: 3). From this fact, marketing is an important factor that determines the success of the company in achieving its goals. Likewise, the pawnshop as one of the BUMNs under the auspices of non-bank financing.

Service quality is the expected level of excellence and control over the level of excellence to satisfy customer excellence (Wickof, in Sulaeman, 2005: 21-22). The modern concept of service quality is building a modern quality system. A modern quality system can be characterized by five characteristics, including: 1) a modern quality system that is aimed at the customer. 2) Active participation led by top management (top management). 3) Knowledge of each of the specific responsibilities for quality. 4) Activities aimed at damage prevention. 5) A philosophy that considers quality to be a way of life (Gaspersz, 2002: 95-97).

The ideal goal of a pawnshop is to provide funds with simple procedures for the wider community, in particular the lower middle class for various purposes, such as consumption, production, etc. (Susilo, et al., 2000: 179). The existence of a pawnshop is also expected to suppress the emergence of non-formal financial institutions that tend to harm the public, such as pengijon, illegal pawnshops, illegal banks, lenders and others. A right of retention is a right acquired by a person who is indebted for a movable object, which is transferred to him by a person who is in debt or by another person on his behalf, and which gives the debtor the power to advance the object in advance. take someone else back; with the exception of the costs of auctioning the goods and the costs of rescuing them after the goods have been pledged, which costs must take precedence in order to obtain a sum of money and the guaranteed goods will be repaid in accordance with the agreement between the customer and the pawnshop (Siamat, 2004: $501)$.

According to Private and Irawan (2002: 5), marketing is a general system of business activities focused on planning, pricing, promotion and distribution of goods and services that meet the needs of both existing and potential buyers. Marketing is the main activity (central activity) of a modern company by effectively serving all human needs (Sentono, 1999: 213). Marketing is a social process whereby individuals and groups get what they need and want by creating, offering and freely sharing valuable products and services with others (Kotler, 2005: 
10). It was therefore concluded that marketing is a process of business activities carried out to plan, determine, promote, and distribute prices and services that can later benefit from this process and meet needs.

Pegadaian Public Company is the only business entity in Indonesia that is officially licensed to carry out activities of financial institutions in the form of financing in the form of distribution of public funds (Budisantoso and Triandaru, 2006: 212). The main activity of Perum Pegadaian Aikmel Branch is a pioneer company. Where this pledge company is a company that is offered by the pawnshop to customers who want to pledge their goods to get a loan based on the pledge law. This pawnshop has a payment term of four months. While subsidiary companies are estimated companies and deposits. In addition, the aikmel branch gives pawnshop loans such as Kreasi (fiduciary repayment credit), the monthly repayment system of which extends during the credit period. The period is 1 to 3 years. Perum Pegadaian Aikmel also cooperates with Western Union in the field of money transfers.

The development or increase in the number of customers in the last three years has increased, in 2017 the number of customers increased by $93 \%$. This is also in line with the sales increase of $34.24 \%$. But in 2018 the increase in the number of customers is only $13.11 \%$, this increase is below the target set by the leadership of the Perum Pegadaian Branch of East Lombok Aikmel. The leaders strive for a $25 \%$ increase every year. A performance under this objective is expected because in 2018 many customers will try to make use of the services of other donors who happen to be new to locations near the pawnshop. In 2019, an increase in the number of customers will reach $22 \%$.

The factors that will be used as variables in this study at Perum Pegadaian Aikmel East Lombok Branch, such as interest rates, loan procedures, services, credit guarantees and facilities, are part of the five service dimensions, namely: Dimensions of tangible include workspace in ownership of the pawnshop is reasonably comfortable and the waiting room is nicely decorated, supported by sufficient facilities. Dimensions of reliability include: the credit amount given by the pawnshop in accordance with the value of the goods pledged by the customer, administrative procedures are easy to follow by the customer and the set interest rate is not too high. Responsiveness dimensions include: employees in the pawnshop always try to be quick and adequate in serving customers, ready and responsive to hear suggestions and complaints from customers. The reliability dimension includes: employees in providing information must be honest and the pawnshop also offers guarantees for goods pledged by customers. The dimensions of empathy are: employees can enter into good relationships, employees can communicate well with customers, employees understand the needs of the customer and employees pay attention to staff for customers.

\section{RESEARCH METHODS}

This type of research method is descriptive research. Descriptive research is a research that investigates the status of a human group or object, a situation situation, a thinking system or 
a class of events in the present with the aim of creating a systematic, factual and accurate descriptive image or painting of facts and properties. the nature and relationship between the phenomena investigated (Nazir, 2005: 63). This investigation of an object, namely Perum Pegadaian Aikmel East Lombok Branch, focused on factors that influence consumers who choose pledge services at Perum Pegadaian East Aikmel Branch.

The data collection method used in this study is the sampling method, which is the method for collecting data by registering a small part of the population or, in other words, only taking the sample (Supranto; 2003: 68). The population in this survey consisted of all customers who pledged their goods at Perum Pegadaian Aikmel East Lombok Branch, with a total of 27,543 people. The number of research samples that no fewer than 100 people have obtained with the Slovin formula (Husein, 2000: 78).

The data collection tool used is a questionnaire that contains a type of question that is given to respondents to obtain the necessary data, especially with regard to the variables examined. Questionnaires are questions that are arranged chronologically based on general questions that specifically refer to respondents / informants who are generally a questionnaire. (Subagyo, 1997: 55). Data collected using this technique relates to the policies of the leaders of the East Lombok Aikmel branch of Perum Pagadaian that affect customers such as: specified interest rates, loan procedures, services, credit guarantees and facilities provided.

The type of data in this study is quantitative data, data in the form of numbers that are calculated and measured with certainty. The quantitative analysis used in this study is factor analysis. In this case the required quantitative data are the number of customers and the turnover at Perum Pegadaian Aikmel East Lombok Branch. According to Suliyanto (2005: 114), factor analysis is a technique for simultaneously analyzing the interdependence of different variables with the aim of simplifying the shape of the relationship between the variables studied to a number of factors that are smaller than the variables studied, which can mean also describe the data structure of an investigation. The research framework is shown in Figure 1 below:

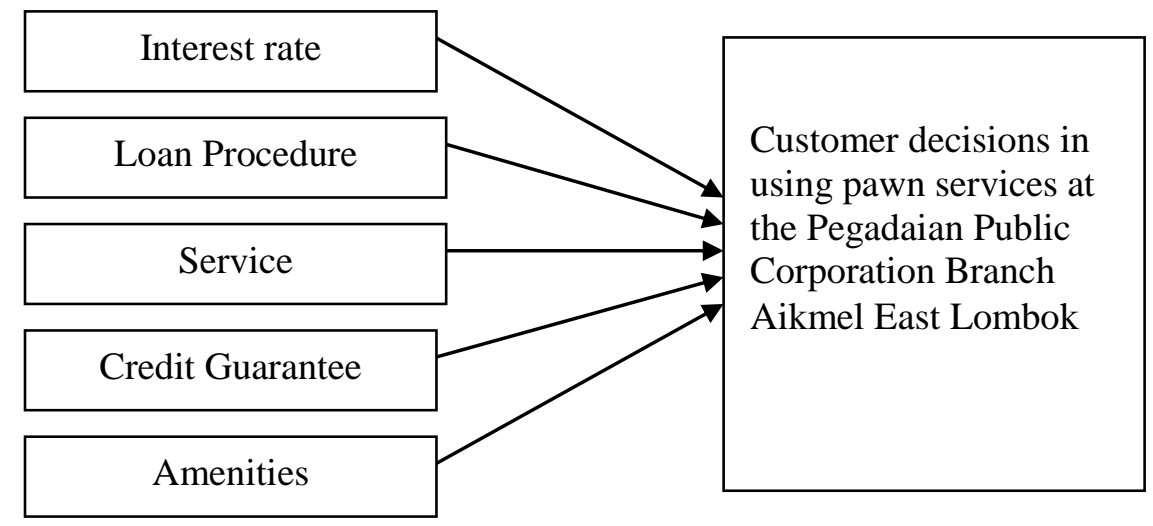

Figure 1:

A framework of factors that influence consumers to pledge goods on Perum Pegadaian Aikmel Branch East Lombok 


\section{FINDINGS AND DISCUSSION}

The quantitative analysis used in this study is factor analysis. True data processing using the Statistics Package for Social Sciences (SPSS) computer program for Windows. The phases of factor analysis using SPSS are performed to find out the factors that influence the consumer's decision to use a pawn service at Perum Pegadaian Aikmel East Lombok Branch.

\section{Data Feasibility Test}

To determine whether or not the factor analysis tool is used in research, it is necessary to meet the conditions that can be derived from Bartlett's Test of Sphericity (BTS) and the results of the Kaiser-Meyer-Olkin (KMO) ) test.

Table 1.

Results of Bartlett's Test of Sphericity (BTS) and Kaiser-Meyer-Olkin (KMO) test results.

\begin{tabular}{lccc}
\hline $\begin{array}{l}\text { Determinant of correlation } \\
\text { matrix }\end{array}$ & Kaiser-Meyer-Olkin (KMO). & Approx Chi Square & sig \\
\hline 0,670 & 0,548 & 38,387 & 0,000 \\
\hline
\end{tabular}

Table 1 shows that the value of the determinant of the correlation matrix is 0.672 The determinant number of the matrix is almost zero, which means that there is sufficient correlation between variables. The KMO value is an index of the distance comparison between the correlation coefficient and the partial correlation coefficient. A small KMO value indicates that factor analysis is not suitable for use. The KMO value is sufficient if it is greater than or equal to 0.5. Based on the output in Table 1 , the KMO value is 0.548 so that the KMO value is $>0.5$. Bartlett's Test shows a figure of 38,387 with a significance of 0.000 . By looking at the determining values, KMO values and Bartlett's test, the correlation matrix is feasible for factor analysis.

\section{Factor Analysis}

To find out the contribution of each variable that influences the consumer's decision to choose to use a pawn service at the Perum Pegadaian Branch of East Lombok Aikmel using factor analysis, the following steps are carried out:

\section{Correlation matrix}

The first step in factor analysis is to create a correlation matrix for all variables, and from that matrix it can be deduced which variables will have multicollinearity. Muliticollinearity will appear if the correlation coefficient is more than 0.80 . From the results of statistical calculations, the first model has a minimum correlation value of 0.251 , namely the correlation between credit guarantees and interest rates, and a maximum correlation value of 0.331 , which is the correlation between credit guarantees and facilities. With a maximum correlation value of 0.331 , the first model can be further analyzed using factor analysis, because the maximum value is lower than 0.80 because a condition of multicollinearity assumptions is met.

2. Selection of variables 
Selecting variables is intended to determine which variables are feasible to be included in factor analysis. All data is entered into the analysis tool using a computer. With SME and Bartlett's sphericity test and anti-image, you get a sample adequacy (MSA) measurement marked with the letter "a" and forms a diagonal on the anti-image matrices. MSAs with values below 0.5 must be excluded from the table list. Appendix 5 shows the MSA of each variable, such as: variable interest rates (650a), loan procedures (517a), services (614a), credit guarantees (539a) and facilities (523a). None of the five variables was excluded from the table because the MSA of each variable was more than 0.5 . The five variables are therefore eligible for inclusion in the factor analysis.

3. Extraction of variables

The next step is extracting variables, that is, changing these variables into factors. Formed factors must have eigenvalues $>1$. Based on the total output variance it can be explained that the number of factors formed is 3 factors, namely the first factor with an eigenvalue of 1,703 , the second factor with an eigenvalue of 1,022 and a third factor with an eigenvalue of 1,003. The component matrix table is used to distribute the extracted variables among the factors formed on the basis of their load factors. Variables are included in the factor with the largest load factor. Factor load indicates the level of proximity of a variable to the variable formed.

4. Matrix factor rotation

In some cases, a condition can be found that a variable has a level of proximity that is relatively the same as different factors formed, so it must be rotated. The rotated component matrix table shows the distribution of variables that have been extracted into factors formed on the basis of factor loads after the rotation process. The value of factor loads can change after rotation. Variables with a factor load $<0.4$ are considered to be a weak contribution to the factors formed, so they must be reduced from the factors in the form.

\section{Table 2.}

Factor Name Variance Explained, Cumulative Total Variants and Other Factors Involved Based on Loading and Eigen Value.

\begin{tabular}{llllll}
\hline No & $\begin{array}{l}\text { Factor name } \\
\text { Varian explanied }\end{array}$ & $\begin{array}{l}\text { Com. Total } \\
\text { varian }\end{array}$ & $\begin{array}{l}\text { Variables involved } \\
\text { in factors }\end{array}$ & $\begin{array}{l}\text { Loading } \\
\text { Factor }\end{array}$ & $\begin{array}{l}\text { Eigen } \\
\text { value }\end{array}$ \\
\hline \multirow{2}{*}{ First Factor } & $34,063 \%$ & Fasility & 0,858 & 1,703 \\
& $\begin{array}{l}(34,063 \%) \\
2\end{array}$ & Second Factor & Credit guarantee & 0,755 & \\
& $(20,441 \%)$ & $54,504 \%$ & Loan Procedure & 0,903 & 1,022 \\
3 & Third Factor & & & & \\
& $(20,058 \%)$ & $74,562 \%$ & Interest rate & 0,760 & 1,003 \\
\hline
\end{tabular}

Service variable is not included in the first factor because after a rotated component matrix the service variable has only a load factor of 0.3365 , less than 0.400 , so it is not enough to contribute to factor 1 . The service variable is also not included in the second factor because it only has a loading factor of 0.282 , less than 0.400 so it is not enough to contribute to factor 2 and 
is not included in the third factor because the service variable has only a loading factor of -0.660 , less than 0.400 so it is not enough to contribute to factor 3 . After being rotated in this study, there are four factors that have an eigenvalue that is greater than or equal to one that is grouped into 3 core factors shown in Table 3.

\section{Table 3:}

Core Factors of each Factor's Eigen Value

\begin{tabular}{lll}
\hline No & Factor & Eigen Value \\
\hline 1 & Credit Facilities and Guarantees & 1,703 \\
2 & Loan Procedure & 1,022 \\
3 & Interest rate & 1,003 \\
\hline
\end{tabular}

The results of the factor analysis show that of the 5 proposed variables, only 4 variables influence the consumer's decision to choose property at Perum Pegadaian Aikmel East Lombok Branch. The first factor has an equity value of 1,703 with a variation of $34,063 \%$ as a combination of variations of credit facilities and guarantees. The second factor has an eigenvalue of 1,022 with a variation of $20,441 \%$, that is, the variable for the loan procedure. The third factor has an eigenvalue of 1,003 with a variation of $20,058 \%$, which is an interest rate variable.

Based on 3, the factors that influence consumer decisions when choosing mortgage services at Perum Pegadaian, Aikmel East Lombok Branch, are composed of four factors being investigated, namely interest rates, credit procedures, services, credit guarantees and facilities . By reducing factor analysis to 3 core factors, the percentage of the total explained variance is $74.562 \%$, which means that this study is able to explain the factors that influence the consumer's decision to pawn in the Aikmel East Lombok Pawnshop Pawnshop Pawnshop of 74,562\% to be used influenced by all variations of factors, while the remaining $25,438 \%$ of customers' decisions to pledge their goods at Perum Pegadaian Aikmel East Lombok Branch influenced by other factors

From the proposed hypothesis that interest rates, loan procedures, services, credit guarantees and facilities that influence consumer decisions when choosing mortgage services at Perum Pegadaian, Aikmel East Lombok Branch are rejected because not all proposed factors have an own value of more than one, Where interest rates, loan procedures, credit guarantees and facilities have an equity value of more than one. However, the service has an eigenvalue of less than one, which excludes it from factor analysis.

Table 4:

Loading factors for each variable after rotating matrix components

\begin{tabular}{lrlll}
\hline \multicolumn{2}{c}{ Variable } & \multicolumn{3}{c}{ Component } \\
\cline { 2 - 4 } & \multicolumn{1}{l}{1} & 2 & 3 \\
\hline \multicolumn{2}{c}{ Amenities } & 0,858 & $-0,203$ & 0,068 \\
Credit & Guarantee & 0,755 & 0,360 & $-0,033$ \\
Loan & Procedure & 0,000 & 0,903 & 0,042 \\
Interest & rate & 0,288 & 0,282 & 0,760 \\
Service & & 0,365 & 0,344 & $-0,660$ \\
\hline
\end{tabular}


Based on the table above, the service variable has no effect on the customer's decision to use the pawn service in the pawnshop of Aikmel East Lombok Branch, because it has a load factor of less than 0.4, while the variable interest rates, credit procedures, Credit guarantees and facilities influence the decision of the customer to pledge the item is due to the loading factor of more than 0.4 .

\section{CONCLUSION AND SUGGESTIONS}

Of the five variables examined consisting of interest rates, loan procedures, services, credit guarantees and facilities, four are variables that influence consumers' decisions to pledge goods at the Perum Pegadaian Branch in East Lombok Aikmel. Of the four variables formed into three factors, namely the first factor consisting of credit facilities and guarantees, the second factor loan procedures and the third factor consisting of interest rates. While the service variable does not affect the consumer's decision to pledge the goods, because it has a load factor of less than 0.4 and the eigenvalues of less than one.

\section{REFERENCE}

Dinawan, M.R. 2020. Analysis of factors that influence purchasing decisions (case study on Yamaha Mio consumers PT Harpindo Jaya Semarang). Indonesian Journal of Marketing Science. IX (3), pp. 335-369

Lupiyoadi, Rambat. 2001. Management, theory and practice of marketing services. First edition. Jakarta: Salemba Empat

Zeithaml, V. A and Bitner. 2000. Service Marketing 2nd edition: Integrating Customer Focus. New York.McGraw-Hill Inc.

Sulaeman, E. R. 2015. Effect of service quality on customer satisfaction (case study of Padacharly VHT Family Karaoke in Garut Branch). Journal of Management, 14 (2).

Gaspersz, V. 2002. Quality management in the service sector. Punt Gramedia Main library: Jakarta

Susilo, Y. Sigit, T. Santoso, T.B. 2000. Banks and other financial institutions. Salemba Empat: Jakarta.

Siamat, Dahlan. 2004. Management of Financial Institutions, Fourth Edition. Faculty of Economics, University of Indonesia: Jakarta.

Swasta, D.H.D, and Irawan. 2002. Modern Marketing Management, Fourth Edition. Liberty Publisher: Jakarta.

Sentono S.P. 1999. Personnel Management. Bandung Alumni Publisher Kotler, P. 2005. Marketing Management 11. Jakarta edition: PT. index

Budisantoso, T and Triandaru, S. 2006. Banks and other Financial Institutions. Edition 2. Salemba Empat: Jakarta.

Nazir. 2005. Research Methods. Bogor: Ghalia Indonesia. 
Supranto, J. 2003. Application Research Methods in Marketing. Seventh Revised Edition. Yogyakarta: Rineka Cipta.

Husein, U. 2000. Marketing Research and Consumer Assessments. Jakarta: PT Gramedia Pustaka.

Soebagyo, J. 1997. Research Methods in Theory And Practice. Jakarta: PT. Rineka Cipta

Suliyanto. 2005. Data Analysis in Marketing Applications. Ghalia Indonesia: Bogor. 